\title{
Indonesia dalam Menjawab Konsep Negara Welfare State dan Tantangannya
}

\author{
Venatius Hadiyono \\ lopid@unika.ac.id \\ Universitas Katolik Soegijapranata, Semarang
}

\begin{abstract}
The concept of a welfare state is the idea that the state is responsible for its citizens, that is, by means of the welfare of its people through services, assistance, protection and prevention of social problems. Indonesia applies this system by adopting a minimal welfare state model, namely by providing a very small budget for social spending. So that social services are provided only for civil servants, Indonesia Military members and private employees who are able to pay the premium. Constitutional support is mentioned in the Indonesian Constitution of 1945, namely Articles 23, 27, 28C, 31, 33, and 34. This is then followed by laws. Number 40 of 2004 concerning the National Social Security System. However, the concept of welfare state is implemented in a minimal model. This is exacerbated by the corruption problems. Indonesia should not only focus on the health sector in realizing the concept of the welfare state, but the education sector can also be a priority to provide an idealistic human resources to create a clean Indonesia for the achievement of the dream of a welfare state.
\end{abstract}

Keywords: Indonesia, Welfare State, Corruption, Poverty

ABSTRAK: Konsep negara kesejahteraan (welfare state) adalah gagasan bahwa negara bertanggung jawab atas warga negaranya, yaitu dengan jalan sejahterakan rakyatnya melalui pelayanan, bantuan, perlindungan dan pencegahan masalah-masalah sosial. Indonesia adalah salah satu peganut sistem ini dengan mengadopsi welfare state model minimal, yaitu dengan memberikan anggaran begitu kecil dalam pembelanjaan sosial. Sehingga pelayanan sosial diberikan hanya secara minimal serta pada umumnya diberikan kepada pegawai negeri, anggota $A B R I$ dan pegawai swasta yang mampu membayar premi. Dukungan secara konstitusional termuat dalam UUD'45 yaitu Pasal 23, 27, 28C, 31, 33, dan 34 yang selanjutnya ditindak lanjuti dengan UU. No. 40 Tahun 2004 tentang Sistem Jaminan Sosial Nasional yang dirasa masih keteteran karena undang-undang yang mestinya mendahuluinya justru terbit belakangan, hal ini justru memperlihatkan ketidak siapan pemerintah untuk menyelenggarakan konsep welfare state sekalipun dengan model minimal. Hal ini diperparah dengan kondisi negara Indonesia yang syarat dengan korupsi yang dapat dibuktikan melalui survay-survay internasional yang menyoroti masalah negaranegara yang dilanda korupsi. Di mana negara Indonesia menduduki rangking 107 negara dari 177 dengan indeks 34 dari 100 (merbupakan angka tertinggi). Seharusnya Indonesia tidak hanya terfokus pada bidang kesehatan saja dalam merealisir konsep welfare state, tetapi bidang pendidikan juga dapat dijadikan prioritas utama karena sebagai penghasil sumber daya manusia yang idealis, bermoral, bermental dan berakhlak untuk menciptakan Indonesia bersih demi tercapainya angan-angan negara kesejahteraan.

Kata kunci: Negara Indonesia, Welfare state, Korupsi, kemiskinan. 


\section{PENDAHULUAN}

\section{LATAR BELAKANG}

Pada abad ke 20 muncul faham demokrasi konstitusional dengan mengusung konsep negara hukum material sebagai bentuk reaksi dari faham demokrasi konstitusional abad ke 19 yang mengusung konsep negara hukum formal. Pengertian sebuah negara yang dikenal dengan negara hukum formal mengedapankan kepentingan individualisme yang berbasis pada kepentingan kaum bangsawan, sehingga negara dengan konsep negara hukum formal itu peranannya menjadi sangat sempit dan pasif, yaitu negara disebut hanya sebagai negara penjaga malam saja ( nacht-wachter staat) dan lebih ekstrim lagi negara hanya menjaga keselamatan dari harta benda kaum bangsawan, melindungi dari pencurian, penipuan, pelaggaranan kontrak, dan gangguan keamanan namun tidak mempunyai hak untuk memonopoli, memaksakan maupun mengatur hubungan antara warga masyarakat. Maka tidaklah heran jika bentuk negara terrsebut bersistem liberalisme yang konsekwensinya muncullah ketimpangan sosial, dan akan juga muncul ketidakadilan dibidang ekonomi.

Oleh sebab itu muncullah reaksi dari konsep negara hukum formal dengan konsepnya sebagai penjaga malam, yaitu negara hukum material atau disebut dengan negara welfare state, sistem ini mengharusan negara untuk bertanggungjawab terhadap kesejahteraan warga masyarakat dengan campurtangan penyelenggara negara yang intensif dan bertanggungjawab terhadap bidang ekonomi dan segala pembangunan yang mengarah kepada pencapaian kesejahteraan masyarakat yang maksimal, dengan memberi kewenangan pada negara untuk ikut campur dalam segala urusan dan kegiatan masyarakat dengan mengingat asas legalitasnya (freies ermess sebuahen).

Konsep wekfare state ini adalah sebuah gagasan negara yang menggunakan sistem pemerintahan yang demokratis yang bertanggungjawab terhadap kesejahteraan rakyatnya. Progaram ini bertujuan untuk mengurangi penderitaan masyarakat seperti kemiskinan, pengangguran, gangguan kesehatan dan lain sebagainya. Oleh karena itu, suatu negara yang menerapkan konsep negara welfare state mempunyai kebijakan publik yang bersifat pelayanan, bantuan, perlindungan atau pencegahan pada masalah sosial. ${ }^{45}$

Negara Inggris adalah negara yang pertama-tama mempunyai ide konsep kesejahteraan sosial, yaitu antara Tahun 1300 sampai dengan pertengahan tahun 1800-an Inggris menerapkan Poor Law (Undang-Undang Kemiskinan), undang-undang ini diterbitkan karena krisis akibat dampak perang yang mengakibatkan banyak terjadinya kelaparan, kemiskinan, penyakit dan kebodohan yang terjadi dimana-mana. Kemudian sistem feodal mengalami kegagalan, dan bersamaan dengan itu tidak terdia bantuan. Pada Tahun 1349 bahkan terjadi musibah yang terkenal dengan sebutan Black Death dimana pada tahun itu banyak sekali korban yang mati dan berakibat berkurangnya populasi penduduk, maka raja Edward kemudian membuat undang-undang (poor Law) yang mengatur masalah pekerja dengan difokuskan pada para gelandangan dan pengemis.

Kemudian tahun 1601 ratu Elizabeth I menerapkan Poor Law dan ini sangat mempengaruhi tingkat kesejahteraan sosial rakyat Inggris dan dikenal dengan Elizabeth Poor Law of 1601. Kemudian pada saat jaman Reneisance menimbulkan benih-benih revolusi industri dan terjadilah gelombang urbanisasi yang tinggi, dan keadaan ini ternyata

\footnotetext{
${ }^{45}$ Miftachul huda, 2009, Pekerjaan Sosial \& Kesejahteraan Sosial: Sebuah Pengantar, Yogyakarta, Pustaka Pelajar, hal. 73.
} 
menimbulkan berbagai persoalan, sehingga mendorong pihak kerajaan untuk memberi bantuan, yaitu dengan membagi Poor Law menjadi dua kategori; Worthy Poor dan Unworthy Poor. ${ }^{46}$

Kategori worthy poor bagi mereka yang tidak memiliki peluang untuk dapat bekerja, keadaan ini wajar jika mereka hidup dalam kemiskinan misalnya, orang lanjut usia, buta, orang cacat, orang tua tunggal dan anak-anak, maka kelompok ini yang mendapat bantuan dari kerajaan Inggris, berupa penempatan di rumah miskin, mendapat pelayanan mendasar untuk kebutuhan hidup.

Kategori Unworthy Poor, mereka miskin karena kemalasan, pemabuk, judi dan tidak mau bekerja sementara itu mereka mempunyai kemampuan untuk bekerja, maka ketegori ini dianggap tidak pantas mendapatkan bantuan dari kerajaan. Bahkan mereka diwajibkan mencari pekerjaan untuk memenuhi kehidupannya, bahkan pemerintah menganjam penjara bagi mereka yang menolak mencari pekerjaan. Merka dianggap mampu bekerja dikirim kepanti untuk mendapat pembinaan dan disalurkan untuk menjadi buruh-buruh disuatu lembaga yang dapat memberi kerja. Poor Law ini diyakini sebagai tonggak sejarah berdirinya negara kesejahteraan atau welfare state.

Kemudian konsep negara Welfare State ini juga dirintis oleh negara Jerman di bawah kepemimpinan Otto Von Bismarck pada tahun 1850-an, dan model ini mengacu pada peranan negara yang aktif dalam mengurus, mengelola dan menorganisir perekonomian, yang di dalam mencakup tanggungjawab negara dalam menjamin adanya pelayanan kesejahteraan dasar bagi warga masyarakatnya. Intinya bahwa negara berupaya menggunakan kebijakan sosial sebagai sarana dalam melakukan penataan ulang pola-pola hubungan warga negaranya, serta berupaya menghapuskan kesenjangan kelas yang ada. Sedangkan untuk mewujudkan negara welfare state itu dibutuhkan 4 persyaratan, yaitu adanya :1. Social citizenship. 2. Full democracy, 3. Modern industial relation system, dan 4. Rights to education dan expansion of modern mass education. Di samping itu negara yang berkonsep negara kesejahteraan ini mengharuskan negara itu harus stabil dalam pemerintahannya, disegala bidang. Hak yang cukup bebas ini kemudian merambah, keranah privat yang termanifestasikan dalam bentuk kebijakan-kebijakan atau peraturanperaturan.

Namun demikian, faham negara kesejahteraan (welfare state) dalam bentuk sosialisme pada pertengahan abad 20 mulai runtuh yang ditandai dengan pecahnya negara Uni Soviet. Hal ini memunculkan paham baru yang disebut dengan neo-liberalisme, yaitu; sebuah faham yang lahir sebagai respon logis terhadap kegagalan sebuah negara dalam membangun kesejahteraan, maka konsep neo-liberalisme mempunyai tujuan untuk mengurangi lagi peran negara yang dirasa terlalu besar, sehinga muncul pemikiranpemikiran privatisasi, yaitu penyelenggara negara harus mengembalikan berbagai urusan publik kepada publik dan tidak lagi diurus oleh negara. oleh sebab itu, negara harus menyediakan ruang-ruang partisipasi publik yang luas supaya rakyat dapat beraktifitas di dalam melaksanakan urusan-urusan publik.

Indonesia adalah salah satu penganut konsep negara hukum yang meterial yang juga mengadopsi konsep-konsep negara wekfare state, dan secara implisit bisa dijumpai pada penjelasan umum UUD'45, serta jika ditelisik secara keseluruhan isi dari UUD'45 dapat ditarik keseimpulan bahwa negara Indonesia merupakan negara hukum yang material atau

${ }^{46}$. Miftachul huda, Ibid, hal.77. 
negara dengan konsep wakfare state dimana negara mempunyai tanggungjawab mutlak untuk memajukan kesejahteraan umum dan mewujudkan keadilan sosial bagi seluruh warga negaranya.

\section{PEMBAHASAN}

\section{A. Model-model Negara welfare State.}

Di dunia ini, ada beberapa model welfare state sesuai dengan idiologi disetiap negara itu, yaitu:

1. Model Institusional (Universal)

Model istitusional ini juga disebut dengan model Universal maupun The Scandinavia Welfare State (dipengaruhi oleh faham liberal). Model ini memandang bahwa kesejahteraan adalah merupakan hak seluruh warga negara, sehingga pelayanan dilakukan secara tetap serta tidak lagi memandang kedudukan sosial dan ekonomi masyarakat. Model ini kemudian diterapkan di negara-negara seperti Swedia, Finlandia, Norwegia dan Denmark.

2. Model Koorporasi (Bismarck)

Model ini seperti model Institution/universal, dan sistem jaminan sosialnya juga dilakukan secara melembaga dan luas, tetapi yang cukup memberi perbedaan adalah kontribusi terhadap berbagai jaminan sosial berasal dari tiga pihak, yaitu pemerintah, dunia usaha dan buruh (pekerja). Dimana pelayanan jaminan sosial diselenggarakan oleh negara dan diberikan kepada mereka yang bekerja atau yang mampu memberikan konstribusi melalui skema asuransi. Konsep ini dianut oleh negara-negara Jerman dan Austria.

3. Model Residual.

Model seperti ini, menerapkan pelayanan yang selektif dan dipengaruhi paham konservatif dan didorong oleh idielogi Neo-liberal dan pasar bebas. Negara memberi pelayanan sosial, khususnya kebutuhan dasar, dan ini diberikan terutama kepada kelompok-kelompok yang kurang beruntung (disadvantaged groups), yaitu kelompok orang miskin, penganggur, penyandang cacat, dan orang lanjut usia yang tidak kaya. Model ini model institusional/universal yang memberikan pelayanan sosial berdasar hak warga negara dan memiliki cakupan yang luas. Tetapi seperti di jalankan di Inggris, jumlah tanggungan dan pelayanan relatif kecil dan berjangka pendek dari pada model institusion/universal. Perlindungan sosial dan pelayanan secara temporer dan diberikan secara ketat dan efisien, serta dalam waktu singkat. Jika sudah dirasa cukup akan segera diberhentikan. Model ini dianut oleh negara-negara Aglo-Saxson meliputi Inggris, Amerika Serikat, Australia dan New Seland.

4. Model Minimal.

Model minimal ini ditandai dengan pengeluaran pemerintah untuk pembangunan sosial yang sangat kecil. Progam jaminan sosial dan kesejahteraan diberikan secara sporadis, parsial dan minimal dan umumnya diberikan kepada pegawai negeri, anggota ABRI dan pegawai swasta yang mampu membayar premi. Model ini pada umumnya memberikan anggaran sangat kecil dalam belanja sosial, karena negara tersebut masih tergolong negara miskin atau bahkan tidak memiliki political wiil terhadap pembangunan dibidang sosial, sehingga pelayanan sosial diberikan secara sporadis, temporal dan minimal. Model ini dianut oleh negara-negara latin seperti; Brazil, Italia, Spanyol, Chilie, sedangkan di kawasan Asia seperti negara Srilanka, Filipina, Korea Selatan dan Indonesia. 
Indonesia masuk kategori model minimal tersebut, bisa dilihat dari landasan dasarnya yaitu UUD'45, UU. No. 40 Tahun 2004 tentang Sistem Jaminan Sosial Nasional serta pengeluaran pemerintah untuk pembangunan sosial masih terlalu kecil. ${ }^{47}$

Sebenarnya konsep negara kesejahteraan sudah dimunculkan sejak masa kemerdekaan dan kemudian han ini diwujudkan dan dipertegas lagi dengan diterbitkannya Undang-undang No.6 tahun 1974 yang menjelaskan konsep Kesejahteraan Sosial yang kemudian disahkan kembali pada tanggal 18 Desember 2008 sebagai penggati undangundang yang lama. Dan dalam Pasal 1 ayat (1) nya menyebutkan, bahwa; "Kesejahteraan sosial adalah kondisi terpenuhinya kebutuhan material, spiritual dan sosial warga negara agar hidup layak dan mampu mengembangkan diri sehingga dapat melaksanakan fungsi sosialnya". Hal ini menjelaskan bahwa jaminan sosial yang dikembangkan pemerintah Indonesia ditujukan untuk mensejahterakan dan mengayomi warga negaranya.

Indonesia memisahkan kategori model, yaitu program jaminan hari tua dan program pemeliharaan kesehatan. Untuk jaminan hari tua, menggunakan sistem tabungan untuk memupuk dana yang akan diberikan sebagai tunjangan hari tua berupa tunjangan pasca karya maupun uang pensiun. Sedangkan dalam bidang kesehatan sebagai elemen penting untuk mencapai kesejahteraan, Indonesia sudah menerapkan sistem asuransi menyeluruh dengan BPJS (Badan Pengelola Jaminas Sosial) sebagai pengelolanya. Namun pelaksanaan asuransi melalui BPJS ini tidak dapat dijangkau oleh semua penduduk indonesia, karena harus melakukan pembayaran premi. Model minimalis yang dipakai Indonesia ditandai dengan hanya memberikan asuransi kesehatan pada keluarga miskin atau dikenal dengan Kartu Indonesia Sehat (KIS), sedangkan bagi mereka yang dikategorikan mampu diharapkan ikut asuransi BPJS, dan bagi mereka yang tidak miskin namun tidak mampu tersedia puskemas yang memberi pelayanan kesehatan murah dan terjangkau. ${ }^{48}$

Bertitik tolak dari uraian di atas, kebijaksanaan sosial dari segi kesehatan penuduk merupakan suatu hal yang menjadi dasar untuk setiap pembangunan, kesehatan menjadi prioritas utama dan merupakan bagian yang diberi dana cukup besar dalam negara Indonesia. ${ }^{49}$ Sebagai negara berkembang Indonesia mempunyai banyak persoalan dibidang sosial seperti masih banyaknya kemiskinan, pengangguran, lingkungan yang tidak sehat, rendahnya pendidikan dan sebagainya, kondisi-kondisi ini banyak menimbulkan kebodohan, rentan penyakit, kesehatan dan kematian.

Oleh sebab itu, konsep negara kesejahteraan ini mempunyai tujuan untuk mengurangai penderitaan masyarakat yaitu dalam bentuk kemiskinan, kesehatan, pengangguran dan sebagainya, sehingga kebijakan-kebijakan pubik negara bersifat pelayanan, perlindungan, pelayan, dan pencegahan terjadinya masalah-masalah sosial. Di samping itu negara yang berkonsep negara kesejahteraan ini mengharuskan negara itu harus stabil dalam pemerintahannya, disegala bidang. Hak yang cukup bebas ini kemudian

\footnotetext{
${ }^{3}$. Bandingkan dengan Edi Suharto, 2009, Kemiskinan dan Perlindungan Sosial di Indonesia, Menggagas Model Jaminan Sosial Universal Bidang Kesehatan, Bandung, Alfabet.

48 . bandingkan Nurhadi, 2007, Mengembangkan Jaminan Sosial, Mengentaskan Kemiskinan, Yagyakarta, Media Sosial, hal. 146

${ }^{49}$ Baca juga dan bandingkan Stewart MacPherson, 1987, Kebijaksanaan Sosian Bagi Dunia Ketiga, Jakarta, PT. Aksara Persada Indonesia, hal. 128
} 
merambah, keranah privat yang termanifestasikan dalam bentuk kebijakan-kebijakan atau peraturan-peraturan.

Indonesia adalah salah satu penganut konsep negara hukum yang meterial yang juga mengadopsi konsep-konsep negara wekfare state, dan secara implisit bisa dijumpai pada penjelasan umum UUD'45, serta jika ditelisik secara keseluruhan isi dari UUD'45 dapat ditarik keseimpulan bahwa negara Indonesia merupakan negara hukum yang material atau negara dengan konsep wakfare state model minimal, dimana negara mempunyai tanggungjawab untuk memajukan kesejahteraan umum dan mewujudkan keadilan sosial bagi seluruh warga negaranya.

\section{B. Bukti Negara Indonesia Menganut Negara Hukum Material (Welfare State).}

Menurut ketentuan alinea IV pembukaan UUD'45 diamanatkan, bahwa; salah satu fungsi pemerintah untuk mencapai tujuan negara, yakni; "melindungi segenap bangsa Indonesia dan seluruh tumpah darah Indonesia dan untuk memajukan kesejahteraan umum, mencerdaskan kehidupan bangsa dan ikut melaksanakan ketertiban dunia berdasarkan kemerdekaan, perdamaian abadi dan keadilan sosial" maka pada alinea IV pembukaan UUD'45 ini jelas memberi pesan terhadap penyelenggara negara untuk selalu berupaya memajukan sejahteraan umum, yang artinya bahwa penyelenggara negara (pemerintah) wajib dengan terus menerus berupaya untuk mencapai sejahteraan warga negaranya. Ini merupakan amanat konstitusi yang tidak bisa diabaikan begitu saja, sehingga penyelenggara negara tidak mungkin bisa lepas dari padanya.

Kemudian Pasal 23 ayat (1) mengamanatkan, bahwa; "Pengelolaan anggaran dan keuangan pemerintah harus diprioritaskan untuk sejahteraan rakyat" ini artinya pembangunan-pembanguan di sektor ekonomi, pendikan, kesehatan dan industri harus memprioritaskan atau mengutamakan peningkatan kesejahteraan warga masyakatnya.

Selanjutnya Pasal 27 ayat (2) mengamanatkan, bahwa; “Tiap-tiap warga negara berhak atas pekerjaan dan penghidupan yang layak bagi kemanusiaan" Pasal ini jelas menjadi jaminan kostitusional bagi warga masyarakat untuk memperoleh pekerjaan, sehingga berpijak pada Pasal 23 ayat (1) di atas, yaitu pengelolaan anggaran dan keuangan pemerintah bisa diarahkan juga untuk pembangunan yang bisa menyerap banyak tenaga kerja. Dengan demikian kebijakan yang seperti bisa jumbuh dengan dengan amanat konstitusonal yang tidak hanya indah untuk dibaca.

Sedangkan pada ketentuan Pasal $28 \mathrm{C}$ memberi landasan konstitusional juga, bahwa rakyat memiliki hak untuk dipenuhi hak-hak dasarnya, maka dengan demikian sangat jelaslah bahwa negara bertangungjawab terhadap hak-hak dasar warga negaranya, yaitu sandang, papan, pangan, pendidikan dan kesehatan, lalu Pasal $28 \mathrm{H}$ lebih dipertegas lagi dengan menyatakan, bahwa setiap orang berhak hidup sejahtera lahir dan batin, bertempat tinggal, dan mendapatkan lingkungan hidup yang baik dan sehat serta berhak memperoleh pelayanan kesehatan, juga mendapatkan kemudahan dan perlakuan khusus untuk memperoleh kesempatan dan manfaat yang sama guna mencapai persamaan dan keadilan, dan juga mendapat jaminan sosial yang memungkinkan pengembangan diri secara utuh sebagai manusia yang bermatabat.

Dan pada ketentuan Pasal 31 memberikan peluang pada masyarakat untuk mendapat pendidikan, bahkan dinyatakan dengan tegas pula bahwa, negara mengatur hak rakyat atas pendidikan dan kewajiban negara untuk memberikan peindidikan setinggitingginya. Ini berarti negara mempunyai tanggungjawab untuk menyelenggarakan 
pembangunan dibidang pendidikan yang mencapai pendidikan tinggi dan menjamin rakyat untuk bisa mengenyamnya.

Oleh sebab itu, di dalam Pasal 33 dan 34 UUD'45 lebih mempertegas lagi, bahwa Pasal 33 mengamanatkan sebagai berikut; pada ayat (1) memberi perintah yakni "Perekonomian disusun sebagai usaha bersama berdasar azas kekeluargaan" yang mempunyai makna bahwa, sistem perekonomian negara Indonesimema merupakan hasil pemikiran bersama dan disusun bersama dan usaha bersama berdasar azaz kekeluargaan untuk meningkatkan kesejahteraan bersama warga masyarakat, ini semua tidak lepas dari konsep-konsep demokrasi konstitusional negara hukum material, jadi kemakmuran rakyatlah yang didahulukan, bukan orang perseorangan. Kemudian ayat (1) ini dilanjutkan pada ayat (2) yang juga memberi penekanan pada konsep negara kesejahteraan (welfare state) yakni memberi amanat sebagai berikut; "Cabang-cabang produksi yang penting bagi negara dan yang menguasai hajad hidup orang banyak dikuasai oleh negara" ini mengandung arti bahwa tidak ada satu-pun dari cabang-cabang produksi yang menguasai hajad hidup orang banyak itu lepas begitu saja dari penyelenggara negara, di sinilah negara harus menjamin keberlangsungannya. Artinya negara melarang adanya penguasaan sumber daya alam berada di dalam tangan perseorangan, yaitu seperti adanya monopoli, oligopoli ataupun adanya praktek kertel yang menyangkut pengelolaan sumber-sumber alam.

Kemudian ayat (3) menegaskan pula, bahwa; "Bumi dan air dan kekayaan alam yang terkandung didalamnya dikuasai oleh negara dan dipergunakan untuk sebesar-besar kemakmuran rakyat" kembali disini negara dituntut untuk mengurus dan kemudian menmgelola yang tujuannya jelas untuk kemakmuran warga masyakatnya. Tidak ada kata tidak ketika sumber-sumber alam tersebut diupayakan untuk meningkatkan kesejahteraan, itu kewajiban penyelenggara negara. Dengan demikian dapat dikatakan, bahwa monopoli pengaturan, penggunaan, penyelengaraan, persediaan serta pemeliharaan sumber daya alam berada ditangan negara. Sedangkan kata "dikuasai oleh negara"bukan berarti kepemilikannya namun cenderung pada kemampuan negara untuk melakukan kontrol dan pengaturan supaya setiap usaha atau perusahaan tetap berpegang pada prinsip kepentingan mayoritas dan kemakmuran rakyat. Pasal 33 ini memiliki jiwa semangat sosial yang menempatkan penguasaan barang untuk kepentingan publik.

Kemudian kembali Pasal 34 menegaskan, bahwa negara Indonesia itu mengurus, artinya berupaya untuk memperhatikan dan memelihara Fakir miskin dan anak-anak terlantar (ayat 1), jelas hal ini menunjukkan bahwa kiprah penyelenggara negara untuk mengurus warga negaranya yang miskin dan anak terlantar. Maka untuk melakukan pekerjaan itu Negara mengembangkan sistem jaminan sosial bagi seluruh rakyat dan memberdayakan masyarakat yang lemah dan tidak mampu sesuai dengan martabat kemanusiaan (ayat 2). Dengan demikan Negara mengambil tanggungjawab atas ketersediaan fasilitas pelayanan umum yang layak (ayat 3), maka dapat dikatakan, bahwa negara tidak hanya mengurus saja, tetapi di sini negara bahkan bertanggungjawab atas tersediannya fasilitas umum yang mestinya dapat digunakan dan dimanfaatkan oleh warga masyarakatnya.

\section{Kesiapan Pemerintah Indonesia}

Bertitik tolak dari ketentuan konstitusional tersebut di atas, maka tidak dapat dipungkiri bahwa Jaminan sosial adalah merupakan hak setiap warga negara, dan negara/pemerintah mempunyai tugas dalam mengembangkan suatu sistem jaminan sosial.

Membahas tentang kesejahteraan tentu kita tidak bisa lepas dari konsep kelas. Setiap masyarakat mempunyai lapisan kelas atas dan bawah. Menurut Miftachul huda 
mengatakan bahwa, berdasar dari hasil Pre-coference Working for the 15 th International Conference of Social Welfare menyebutkan bahwa, Kesejahteraan sosial adalah keseluruhan usaha sosial yang terorganisir dan mempunyai tujuan utama untuk meningkatkan taraf hidup masyarkat berdasarkan konteks sosial. Di dalamnya tercakup juga unsur kebijakan dan pelayanan dalam arti luas yang terkait dengan berbagai kehidupan dalam masyarakat, seperti pendapatan, jaminan sosial, kesehatan, perumahan, pendidikan, rekreasi budaya, dan lain sebagainya..$^{\circ}$

Tidak semua orang memiliki kemampuan untuk memenuhi kebutuhan hidupnya oleh karena itu peran pemerintah sebagai pemimpin negara sangat dibutuhkan untuk membantu kemerataaan kesejahteraan dari setiap kelas yang ada dalam masyarakat. Dalam sebuah negara, kesejahteraan dikaitkan dengan peran pemerintah untuk memenuhi kebutuhan warganya dalam bidang kesehatan, pendidikan dan rasa aman

Maka sudah semestinya pemerintah membuat peraturan perundang-undangan tentang sistem jaminan sosial, tentunya dalam pembuatan peraturan itu pemerintah akan mengingat ketentuan Pasal 28H secara utuh menyeluruh dan Pasal 34 ayat (1) dan ayat (2). Kebijakan seperti disebutkan dalam ketentuan Pasal 34 tentang fakir miskin dan anak terlantar serta jaminan sosial, ketersediaan fasilitas pelayanan umum dan masalah kesehatan akan saling menguatkan satu dengan yang lainnya, sehingga hak-hak sebagaimana diamanatkan Pasal 28H UUD'45 dapat dilaksanakan.

Namun demikian ada kelalaian pemerintah, bahwa amanat Pasal 34 ternyata dilaksanakan secara terpisah tidak utuh menyuluruh sebagaimana ketentuan Pasal $28 \mathrm{H}$, dari semua ayatnya dilaksanakan secara utuh menyeluruh yaitu dari ayat (1) sampai dengan ayat (3) yang mengamanatkan sebagai berikut :

ayat (1). Setiap orang berhak sejahtera lahir dan batin, bertempat tinggal,; dan mendapatkan lingkungan hidup yang baik dan sehat serta berhak memperoleh pelayanan kesehatan.

ayat (2). Setiap orang berhak mndapat kemudahan dan perlakuan khusus untuk memperoleh kesempatan dan manfaat yang sama guna mencapai persamaan dan keadilan.

ayat (3). Setiap orang berhak atas jaminan sosial yang memungkinkan pengembangan dirinya secara utuh sebagai manusia yang bermatabat.

Namun demikian tidak halnya dengan Pasal 34 yang mestinya juga sebagai mengingat, dan ini seharusnya dimuat secara utuh menyuluruh yaitu :

ayat (1). Fakir miskin dan anak-anak terlantar dipelihara oleh negara.

ayat (2). Negara mengembangkan sistem sosial bagi seluruh rakyat dan memberdayakan masyarakat yang lemah dan tidak mampu sesuai dengan martabat kemanusiaan.

ayat (3).Negara bertanggungjawab atas penyediaan fasilitas pelayanan kesehatan dan fasilitas pelayanan umum yang layak.

ayat (4) Ketentuan lebih lanjut mengenai pelaksanaan pasal ini diatur dalam undangundang.

Sayang ketika Pemerintah bersemangat untuk segera menjalankan dan mengembangkan sistem jaminan sosial dengan mengeluarkan undang-undang tentang sistem jaminan sosial nasional yaitu UU. No. 40 Tahun 2004, pemerintah telah melupakan ketentuan Pasal 34 ayat ( 3 dan 4) dalam ketentuan mengingatnya, seharusnya pemerintah faham betul bahwa Pasal 34 tidak bisa dibaca ayat-perayat, sehingga pasal itu harus dibaca dan dimengerti secara utuh menyeluruh dan tidak dipisahkan. Pengabaian ayat (3) yang

50 . Ibid 
menyatakan, Negara bertanggungjawab atas kesediaan fasilitas pelayanan kesehatan dan fasilitas umum yang layak tidak menjadi pertimbangan yang penting, sehingga implikasinya terhadap adanya kesedianaan fasilitas kesehatan dan fasilitas umum tidak menjadi perhatian, demikian juga ketika ayat (4) terabaikan.

Mestinya sesuai dengan perundang-undangan sesuatu itu diatur secara berurutan, tetapi disini UU tentang Sistem Jaminan Sosial Nasional disusun dan dilahirkan lebih awal dari undang-undang yang seharusnya disusun dan diundangkan mendahului undang-undang sistem jaminan sosial nasional ini. UU. Sistem Jaminan Sosial Nasional dikeluarkan Tahun 2004, yaitu dengan UU. No. 40 Tahun 2004. Baru kemudian pada Tahun 2009 pemerintah megeluarkan UU. No. 11 Tahun 2009 tentang Kesehatan Sosial, yang disusul dengan UU. No. 25 Tahun 2009 tentang Pelayanan Publik dan kemudian UU. No. 36 Tahun 2009 tentang kesehatan, UU. No. 13 Tahun 11 tentang Penanganan Fakir Miskin, serta UU. No. 2 Tahun 2012 tentang Pengadaan Tanah bagi Pembangunan untuk Fasilitas Umum, dari fakta yang demikian ini, jelas pemerintah telah mengabaikan amanat UUD,45 khususnya Pasal 34 ayat (3) dan ayat (4), yang seharusnya pemerintah menyusun dan mengeluarkan UU. No. 11 Tahun 2009 tentang Kesehatan Sosial, UU. No. 25 Tahun 2009, UU. No. 36 Tahun 2009 serta disusul dengan UU.No. 13 Tahun 2011 tentang Penanganan Fakir Miskin, UU. No. 2 Tahun2012 tentang Pengadaan Tanah bagi Pembangunan utuk kepentingan Umum, kemudian barulah disusun dan dikeluarkan UU. Seperti UU No 40 Tahun 2004 tersebut.

Lalu apakah ini yang dikehendaki konsep negara berasaskan welfare state? Tentunya bukan, sebuah konsep negara welfare state seharusnya di kemas sedemikian rapi, sehingga tatakelola dari apapun menjadi baik dan tertata, bukan yang asal sudah mengeluarkan undang-undang yang menyentuh kesejahteraan warga masyarakatnya disusun dan dikeluarkan begitu saja tanpa kesiapan perangkat yang akan pendukungnya. Maka sangatlah jelas bahwa Pemerintah Indonesia belum bisa menyikapi konsep negara kesejahteraan dengan tepat dan benar sesuai dengan amanat UUD'45, namun demikian usaha untuk mengarah ke konsep walfare state sudah jalas.

Tampak di sini bahwa, pemerintah berkeinginan sistem jaminan sosial nasional yang diatur dengan UU. No. 40 Tahun 2004, dipaksakan hadir sehingga meningalkan undangundang yang seharusnya disusun dan diundangkan terlebih dulu, Seakan-akan ada kepentingan yang mendesak tanpa kosep persiapan yang matang. Jika pemerintah membuat kebijakan sistem jaminan sosial mestinya dipersiapkan dulu piranti pendukungnya, sistem ini tidak akan berjalan dengan semestinya jika untuk penopang sistem itu belum ada. Semisal sistem jaminan sosial itu ada tetapi bagaimana sistem kesehatannya belum diatur bagaimana sistem yang dibuat itu bisa efektif berjalan, sedangkan salah satu pengaturan itu adalah bidang kesehatan, belum lagi untuk pelayanan kesehatannya dan pelayanan publik juga belum diatur, lalu bagaimana sistem ini bisa berkerja, dan siapa yang akan tekena sistem itupun belum juga diatur.

Sistem Jaminan Sosial Nasional ini kemudian menjadi prioritas pemerintah dalam upaya pengentasan kemiskinan dan meningkatkan kesejahteraan utamanya di bidang kesehatan, kebijakan ini menjadi isu yang amat strategis yang dicoba diangkat dengan dasar alasan peningkatan kesejahteraan masyarakat, sehingga pada tahun 2013 pemerintah mengeluarkan Pen Pres No.12 Tahun 2013 tentang Kesehatan dan Pen Pres No. 7 Tahun 2012 tentang Sistem Kesehatan Nasional (SKN) sebagai amanat adanya UU. No.40 Tahun 2004. 
Keberadaan Penpres-Penpres ini sebenarnya untuk terlaksananya UU. No. 40 Tahun 2004 tentang Sistem Jaminan Sosial Nasional yang dicanangkan per 1 Januari 2014 akan diterapkan, namun terlihat disini bahwa jelas keberadaan undang-udang ini telah mengabaikan Pasal 34 ayat (3) dan ayat (4). Belum lagi jika ditilik dari kesiapannya, UU. No. 40 Tahun 2004 tentang Sistem Jaminan Sosial Nasional bidang kesehatan ini belumlah layak diterapkan karena kesediaan fasilitas pelayanan kesehatan belum cukup tersedia sedangkan tersedianya akan hal itu ini jelas merupakan perintah dari konstitusi yang harus disiapkan dalam bentuk undang-undang.

Perintah Konstitusi itu diaksanakan, akan tetapi Pemerintah tampaknya hanya terfokus menyusun peraturan perundang-undangan tentang kesehatan saja, sedangkan penunjang untuk itu hanya diatur melalui Peraturan Menteri Kesehatan (Permenkes) saja. sedangkan pengaturan tentang fasilitas pelayanan kesehatan baru disahkan setelah Undang-Undang No 40 Tahun 2004 tentang Sistem Jaminan Sosial Nasional disahkan, yaitu Undang-undang No. 44 Tahun 2009 tentang Rumah Sakit dan Peraturan Presiden No. 28 Tahun 2011 tentang klinik, ini menandakan betapa Pemerintah sangat tidak memperhatikan terlebih dulu untuk pendukung kesiapan dilaksanakan UU. No. 40 Tahun 2004. Demikian juga dengan Peraturan Menteri Kesehatan No. 6 Tahun 2013 tentang Kriteria Fasilitas Pelayanan Kesehatan baru dibuat setelah disahkannya Undang-undang No. 13 Tahun 2013 tentang Badan Penyelengara Jaminan Sosial (BPJS).

Kebijakan-kebijakan itu dibuat karena didorong keinginan pemerintah supaya segera berlakunya UU. Sistem Jaminan Sosial Nasional segera efektif terlaksana pada tanggal 1 Januari 2014. Tampaknya isu kesehatan bagi pemerintah merupakan isu sentral yang perlu segera digarap walaupun maninggalkan isu sosial yang lain yang mungkin penting harus segera dipikirkan juga. Namun aturan-aturan tentang fasilitas pelayanan kesehatan terlihat dipisah-pisah tidak dipadukan menjadi satu kesatuan, dan yang paling riskan adalah peraturan fasilitas pelayanan kesehatan tersebut terkesan membiarkan praktek-praktek bisnis komersialisasi asuransi kesehatan, bisnis rumah sakit dan klinik, mafia farmasi, peluang adanya kolusi dalam akreditasi fasilitas kesehatan, bahkan terbukanya komersialisasi pendidikan kedokteran tercecernya peraturan-peraturan dibidang pelayanan kesehatan tersebut, tampaknya pemerintah belum begitu siap dengan dilaksanakannya UU. No. 40 Tahun 2004 Sistem Jaminan Sosial Nasional, mestinya pemerintah lebih mengatur dulu bidang-bidang sosial yang menjadi target sasaran dari UU. No. 40 Tahun 2004 tersebut.

\section{Solusi Efektif.}

Hasil penelitian TII (Transparency International Indonesia) tahun 2019 Indeks persepsi Indonesia ada di skor 40 dan termasuk negara terkorup peringkat ke 85 dunia dari 180 negara. Sedangkan di tingkat Asean Indonesia berada di tingkat $4 .{ }^{51}$ dengan skala 01-100 (asumsi skor 100 dianggap negara paling bersih dari korupsi dan skor paling rendah dianggap negara paling korup).

Melihat kondisi seperti ini mestinya pemerintah menyehatkan dulu lembagalembaga negara yang syarat dengan adanya korupsi dan kolusi, terutama pada lembaga negara yang bersentuhan dengan Sistem Jaminan Sosial Nasional seperti misalnya lembaga negara dibidang perpajakan yang berperan sebagai lembaga pengelola sumber daya

\footnotetext{
${ }^{51} \mathrm{https}$ ///www.cnnindonesia.com/nasional/20200123164232-12-468074/tii-skor-indeks-persepsikorupsi-indonesia-naik-jadi-40
} 
negara, departemen sosial, departemen keuangan, departemen pendidikan departemen kesehatan, departemen agama, departemen tenaga kerja dan sebagainya, supaya kelembagaan negara Indonesia dapat dipastikan kebersihan dan kesehatannya, sehingga baru bisa bicara penyelenggaraan Sistem Jaminan Sosial Nasional dengan baik dan tanpa hambatan.

\section{PENUTUP \\ SIMPULAN}

Negara Indonesia sebagai negara yang berkembang dengan sistem welfare state dengan model minimalis tetap memberikan tunjangan yang sangat menimal juga bagi warga negaranya. Dengan demikian, sudah semestinya masyarakat tidak terus menerus mengandalkan bantuan dan tergantung pada pemerintah. Tanggungjawab kesejahteraan pribadi terletak pada masing-masing pribadi itu sendiri, tanpa mengandalkan bantuan pemerintahan yang masih dirongrong adanya perbuatan-perbuatan korup. Sebenarnya jika Pemerintah itu tidak hanya terfokus dan mengutamakan sistem jaminan sosial nasional pada kesehatan saja yang nyatanya masih keteteran, pemerintah mestinya juga memfokuskan serta mengefektifkan perbaikan kualitas sumber daya manusia terlebih dulu yaitu dengan memperbaiki dan membangun aspek moral dan mental manusianya.

Oleh sebab itu kualitas sumber daya manusia diupayakan peningkatannya melalui jenjang pendidikan dan ini mestinya harus diperhatikan dan diprioritaskan menjadi fokus yang utama pemerintah. Karena dari dunia pendidikan inilah moral, mental dan ahklak manusia dibentuk, sehingga menghasilkan manusia-manusia yang terdidik dan mempunyai idealisme tinggi serta anti korupsi.

Melihat pada ketidak berdayaan pemerintah ini, memberi sinyal bahwa negara dalam menjawab dan mengejawantahkan konsep negara kesejahteraan (wefare state) walaupun dengan model yang minimal sekalipun, belumlah begitu siap. Ketidak siapan negara justru pada sumber daya manusianya yang bermental korup dan masih mengunakan kebijakan-kebijakan jaminan sosial untuk kepentingan politik semata.

\section{DAFTAR PUSTAKA}

Edi Suharto, 2009, Kemiskinan dan Perlindungan Sosial di Indonesia, Menggagas Model Jaminan Sosial Universal Bidang Kesehatan, Bandung, Alfabet.

Miftachul huda, 2009, Pekerjaan Sosial \& Kesejahteraan Sosial: Sebuah Pengantar, Yogyakarta, Pustaka Pelajar.

Nurhadi, 2007, Mengembangkan Jaminan Sosial, Mengentaskan Kemiskinan, Yogyakarta, Media Sosial.

Stewart MacPherson, 1987, Kebijaksanaan Sosial Bagi Dunia Ketiga, Jakarta, PT. Aksara Persada Indonesia.

http://www.tahupedia.com/content/show/587/10-Negara-Terkorup-Di-Dunia, Oleh raza dalam Top pada March 05, 2015, di uduh tagl 2 Juli 2915

http://www.dream.co.id/news/indonesia-masuk-daftar-negara-terkorup-di-dunia141208l.html. diunduh 2 juli 2015. 